\title{
Combined Soil Treatments and Sequence of Application in Improving the Control of Soilborne Pathogens
}

\author{
Dani Eshel, Abraham Gamliel, Avshalom Grinstein, Pietro Di Primo, and Jaacov Katan
}

First, second, and third authors: Laboratory for Pest Management Application, Institute of Agricultural Engineering, ARO, The Volcani Center, P.O. Box 6, Bet Dagan 50250, Israel; fourth author: Dipartimento di Agrochimica e Agrobiologia, Universita' degli Studi di Reggio Calabria, Piazza San Francesco, 2-89061 Gallina (RC), Italy; and fifth author: Department of Plant Pathology and Microbiology,

The Hebrew University of Jerusalem, Faculty of Agricultural, Food and Environmental Quality Sciences, Rehovot, 76100, Israel. Accepted for publication 14 March 2000.

\begin{abstract}
Eshel, D., Gamliel, A., Grinstein, A., Di Primo, P., and Katan J. 2000. Combined soil treatments and sequence of application in improving the control of soilborne pathogens. Phytopathology 90:751-757.

The effects of reduced doses of methyl bromide (MB) or metham sodium, heating, short solarization, and soil microbial activity, alone or in combination, on survival of soilborne fungal pathogens were tested in a controlled-environment system and field plots. Sublethal doses of heating or MB delayed germination of Sclerotium rolfsii sclerotia. Combining $\mathrm{MB}$ and heating treatments was more effective than either treatment alone in controlling $S$. rolfsii and Fusarium oxysporum f. sp. basilici. The application heating followed by fumigation with $\mathrm{MB}$, was significantly

Further, incubation in soil and exposure to microbial activity of previously heated or MB-treated sclerotia increased the mortality rate, indicating a weakening effect. Similarly, incubation of chlamydospores of $F$. oxysporum f. sp. melonis and $F$. oxysporum f. sp. radicis-lycopersici in soil in the field after fumigation further reduced their survival, confirming the laboratory results. In field tests, combining $\mathrm{MB}$ or metham sodium at reduced doses with short solarization was more effective in controlling fungal pathogens than either treatment alone. Treatment sequence significantly affected pathogen control in the field, similar to its effect under controlled conditions. This study demonstrates a frequent synergistic effect of combining soil treatments and its potential for improving pathogen control and reducing pesticide dose, especially when an appropriate sequence was followed.
\end{abstract} more effective in delaying and reducing germination of $S$. rolfsii sclerotia and in controlling $F$. oxysporum f. sp. basilici than the opposite sequence.
Additional keywords: biocontrol, fumigant, soil disinfestation, vapam.
The coming phaseout of methyl bromide (MB), a major soil fumigant worldwide, has intensified the need for new control methods, as well as the improvement of existing ones, to achieve acceptable levels of control without negatively affecting the environment. Combining tactics is a major tool in integrated pest management and is one of the most feasible approaches in this regard (17). Indeed, the combination of fumigants at reduced doses, soil solarization, antagonists, or other agents improves pathogen control $(3,9,10,13,14,16,21-23)$. Although MB will be phased out in developed countries in 2005, its use will continue for a specified period in developing countries, as well as for particular critical uses in other countries. Therefore, means of reducing MB usage, while maintaining its effectiveness, are still needed, and this holds true for other fumigants as well. The use of sublethal doses of killing agents weakens the pathogen and enables effective control while minimizing dose $(10,11,18,20,23)$. Thus, weakening pathogen propagules by sublethal soil treatment increases their vulnerability to other agents in the soil, such as chemicals, heat, and soil microbial antagonists. This can lead to the enhancement of biological control of the partially damaged propagules by soil organisms $(2,10,18,20)$.

The objectives of this study were to test the possibility of reducing soil fumigant doses and shortening soil solarization periods by successive treatment applications in two application

Corresponding author: A. Gamliel; E-mail address: agamliel@agri.huji.ac.il

Publication no. P-2000-0501-01R

This article is in the public domain and not copyrightable. It may be freely reprinted with customary crediting of the source. The American Phytopathological Society, 2000. sequences in a controlled system and in soil under field conditions.

\section{MATERIALS AND METHODS}

Soils. Two types of soil were used: an agricultural sandy soil from Rehovot, Israel (0.5\% organic matter, $95.7 \%$ sand, $3.8 \%$ clay, $\mathrm{pH} 7.9$, water holding capacity $9 \%$, wt/wt), and an acidwashed marine sand (Sigma Chemical Company, St. Louis) with a water-holding capacity of $5 \%$ (wt/wt), which was sterilized by autoclaving ( $120^{\circ} \mathrm{C}$ for $\left.20 \mathrm{~min}\right)$.

Pathogens and inoculum preparation. Propagules of four pathogenic soil fungi were used in these studies. Macroconidia of Fusarium oxysporum Schlechtend. f. sp. basilici (Dzidzarya) Armstr. \& Armstr. were collected from sporulating lesions on stems of sweet basil (Ocimum basilicum L.) from a crop severely affected by the pathogen. The outer tissue of stems showing pink spore masses was stripped off with a scalpel and kept at room temperature until use. Immediately before use, the peel was cut into $1 \mathrm{~cm}$ lengths.

Soil from a greenhouse with diseased basil plants naturally infested with $F$. oxysporum f. sp. basilici and soil from a field with diseased tomato plants infected with $F$. oxysporum f. sp. radicislycopersici were collected and air-dried and served as natural inocula. The soils were stored for up to 9 months at room temperature, and before use, the density of chlamydospores as determined by microscopic observation, was assayed by a soil dilution method (12). Samples of F. oxysporum isolates from these soils were used to inoculate their respective host (basil or tomato) in order to verify their identity.

Chlamydospores of F. oxysporum f. sp. melonis, originally isolated from diseased muskmelon plants, were produced in soil. 
Conidia of the pathogen were suspended in water, mixed with sandy Rehovot soil and incubated for 100 to 120 days at $27^{\circ} \mathrm{C}$, after which only chlamydospores remained in the soil, as verified by microscopic examination. The infested soil was air-dried and stored at $8^{\circ} \mathrm{C}$ until use.

Sclerotium rolfsii Sacc. was initially isolated from diseased bean seedlings. Sclerotia were obtained from a culture of the pathogen grown on potato dextrose agar (PDA) (7) at $27^{\circ} \mathrm{C}$ for 30 days. Sclerotia were collected after being air-dried at room temperature and tested for their viability by plating on PDA prior to each experiment. All the experiments were carried out using samples from one preparation of sclerotia.

Before each experiment, the pathogen was mixed with 100- to $250-\mathrm{g}$ soil or sand samples that had been brought to the desired water content (1\%, (wt/wt), in sand and $1.8 \%$ in Rehovot soil) (8) and preincubated for $24 \mathrm{~h}$. Moistened soil or sand $(5 \mathrm{~g})$, containing the test material was poured into a nylon net bag. Bags were exposed to various sets of conditions in the apparatus described below, in triplicate.

Fumigation apparatus and procedure. A controlledenvironment system was designed for this study, using a previously described fumigation apparatus (8). Narrow-neck glass containers (13 cm diameter, $25 \mathrm{~cm}$ high, 2 liter volume) were used as fumigation chambers. Each container was sealed with a glass lid and screw ring. The lid had two ports, both controlled by gastight valves (Elchem Plastic, Kibbutz Baram, Israel). Tubing (nylon 11; $5 \mathrm{~mm}$ diameter, 1-mm-thick wall) was used to connect the container to a pump for MB circulation and measurement. A rubber septum was installed in a third part located at the top of the

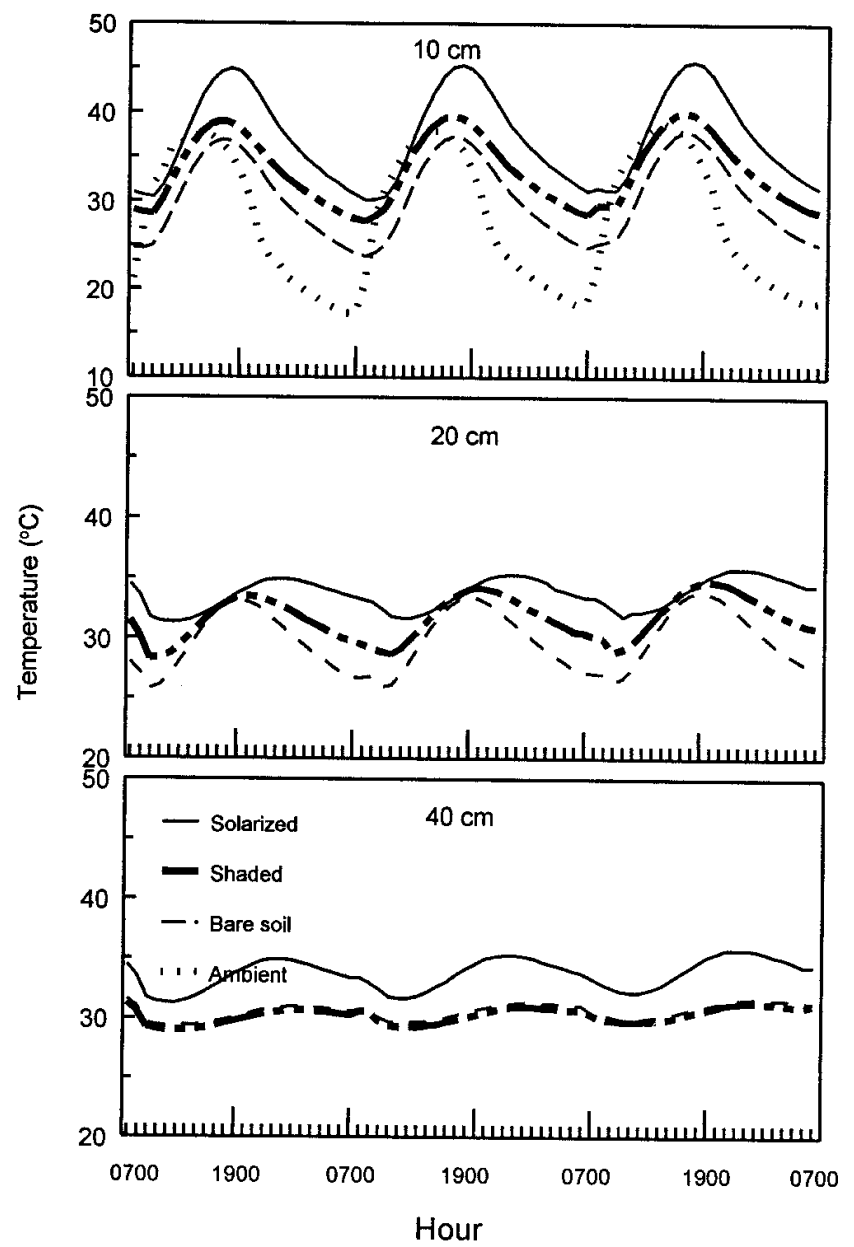

Fig. 1. Ambient and soil temperatures at three soil depths under plastic films or shading during fumigation with methyl bromide and solarization (July 1996). lid and used to inject the gas into the container. MB (100\%, Dead Sea Bromine, Beer-Sheva, Israel) was injected as a gas into the container at a predetermined volume with a syringe. A calibration curve was used to determine the gas volume needed to achieve the appropriate $\mathrm{MB}$ concentration in the container atmosphere.

Methyl bromide was applied at rates ranging from 25 to $44 \mathrm{~g} \mathrm{~m}^{-3}$ air, as indicated. Concentrations of MB in the containers were measured with a gas analyzer (Fumiscope-D, Statpower Technologies Corp., Burnaby, BC, Canada) equipped with a pump and thermal conductivity detector. The gas analyzer was connected to each container and the vessel atmosphere was circulated for $5 \mathrm{~min}$ through the detector, at a flow rate of 1 liter $\mathrm{min}^{-1}$. Gas measurements were repeated at the end of the exposure period. At the end of each experiment, the containers were opened in a fumehood, and the MB was captured in an absorbent charcoal filter.

Assessing the viability of fungal populations. $S$. rolfsii sclerotia were retrieved from the bags by sieving, washed, and tested for viability by evaluating germination, as previously described (12). Stem peel pieces of sweet basil infected with $F$. oxysporum f. sp. Basilici, with typical pink spore masses, were recovered from the bags and agitated (Vortex-Genie, Springfield, MA) for $15 \mathrm{~s}$ at the highest setting in $2 \mathrm{ml}$ of distilled water. The number of $F$. oxysporum f. sp. basilici macroconidia suspended in the water was adjusted to $5 \times 10^{5} \mathrm{ml}^{-1}$ with a hemacytometer. Aliquots $(100 \mu \mathrm{l})$ of the suspension were then plated on petri dishes with peptone-pentachloronitrobenzene Fusarium selective medium (7). Viability was assessed by incubating plates for 10 to $14 \mathrm{~h}$ at $27^{\circ} \mathrm{C}$ and determining the percentage of germination by direct microscopic examination.

Microbial counts by soil dilution. Each of three 5-g soil subsamples of each replicate (naturally infested with $F$. oxysporum f. sp. basilici, $F$. oxysporum f. sp. radicis-lycopersici, or $F$. oxysporum f. sp. melonis) was added to $45 \mathrm{ml}$ of sterile water agar $(0.1 \%$, wt $/ \mathrm{vol})$ containing $\mathrm{MgSO}_{4} \cdot 7 \mathrm{H}_{2} \mathrm{O}(0.1 \%$, wt/vol). The samples were shaken for $15 \mathrm{~min}$ on a reciprocal shaker and then serially diluted with the same solution (down to $10^{-3}$ spores per $\mathrm{ml}$ ). Samples of $0.2 \mathrm{ml}$ were spread on five petri dishes that contained Fusarium-selective agar medium (7). Plates were incubated in the dark at $28^{\circ} \mathrm{C}$ for 4 to 6 days. Results are expressed as colony forming units per gram of soil (dried at $105^{\circ} \mathrm{C}$ for $48 \mathrm{~h}$ ).

Heating apparatus and procedure. Propagules mixed with moistened sand were transferred to glass tubes $(1.5 \mathrm{~cm}$ diameter, $2.5 \mathrm{ml}$ ). The tubes were sealed with Parafilm to minimize evaporation. Samples were heated in a water bath using a circulation heating system (Tep-3, Fried Electric, Haifa, Israel), with an accuracy of $\pm 0.1^{\circ} \mathrm{C}$.

Exposure to soil microbial activity in laboratory applications. Propagules of $S$. rolfsii that were treated with MB or heat and untreated sclerotia were incorporated in pots filled with moistened Rehovot soil. The pots were kept in a controlledtemperature chamber at $27^{\circ} \mathrm{C}$. A second set of treated samples, serving as a control, was kept in dry sterile sand.

Fumigation and solarization in field experiments. Four sets of field trials were carried out from 1995 to 1998 to test the effect of short solarization (8 days), fumigation with $\mathrm{MB}$ or metham sodium (Edigan, Agan-Makteshim Chemicals, Ashdod, Israel) at reduced doses, and a combination of the two treatments using two different application sequences. All experiments were carried out during the summer months (June through August) at the experimental farm of the Hebrew University in Rehovot, in sandy soil (3.8\% clay, $95.7 \%$ sand, $0.5 \%$ organic matter, $\mathrm{pH} 7.9$ ). Ambient and soil temperatures during the experimental period are given in Figure 1.

Plots $(4 \times 4 \mathrm{~m})$ were outlined, and trenches $(30 \mathrm{~cm}$ deep) were cut to bury the plastic edges. Gas-sampling tubing (nylon 11; 5 $\mathrm{mm}$ diameter, $5 \mathrm{~m}$ long) was placed in the center of each plot at 
various depths before the plastic tarps were laid, as previously described (12). The buried end of the tubing was protected with a porous plastic cylinder (10 $\mathrm{cm}$ long $\times 15 \mathrm{~mm}$ diameter $)$. The other end was extended to an area outside the mulched plot. All plots were mulched with low-density polyethylene film (Polyon, Barkay, Israel). Fungal inocula were buried in the soil at the center of each plot before laying the plastic film. Mulched plots in which solarization was not desired during part or the duration of the experiments were shaded by covering with an Aluminet screen giving $90 \%$ shading capacity (Polysak, Barkay, Israel). The screen was stretched over the plots, leaving a $30 \mathrm{~cm}$ space over the plastic film. Treatments included short solarization (8 days), MB fumigation at low doses of $10 \mathrm{~g} \mathrm{~m}^{-2}$ or metham sodium at $10 \mathrm{ml}$ $\mathrm{m}^{-2}$ (both under shading to prevent any effect of solarization), and a combination of each fumigant with solarization. Two sequences of combined applications were tested. Application of the first sequence was the fumigant under polyethylene film and shading screen for $48 \mathrm{~h}$ followed by removal of the screen and allowing an additional 8 days of solarization. The second sequence was initiated with 8 days of solarization followed by application of MB with shading of the plots for an additional 2 days. MB (Methabrom, 98\% a.i., Dead Sea Bromine) was applied to preirrigated soil through drip lines that were placed under the film, using the hot gas method (19). MB concentration $(C)$ in the soil was determined periodically following its application over time (T) during a 5-day period by connecting the sampling tubing to a 20-800 gas analyzer (GowMac Instrument Co., Bridgewater, NJ). Thus, $C \times T$ values were determined by calculating the area under the MB concentration times the time curve (12). Metham sodium was applied by drenching with 30 liters of water per $\mathrm{m}^{2}$.

Statistical analyses. Each field experiment was conducted at least twice in the same area and with the same soil type. Separate analysis of each experiment showed homogeneous variances of
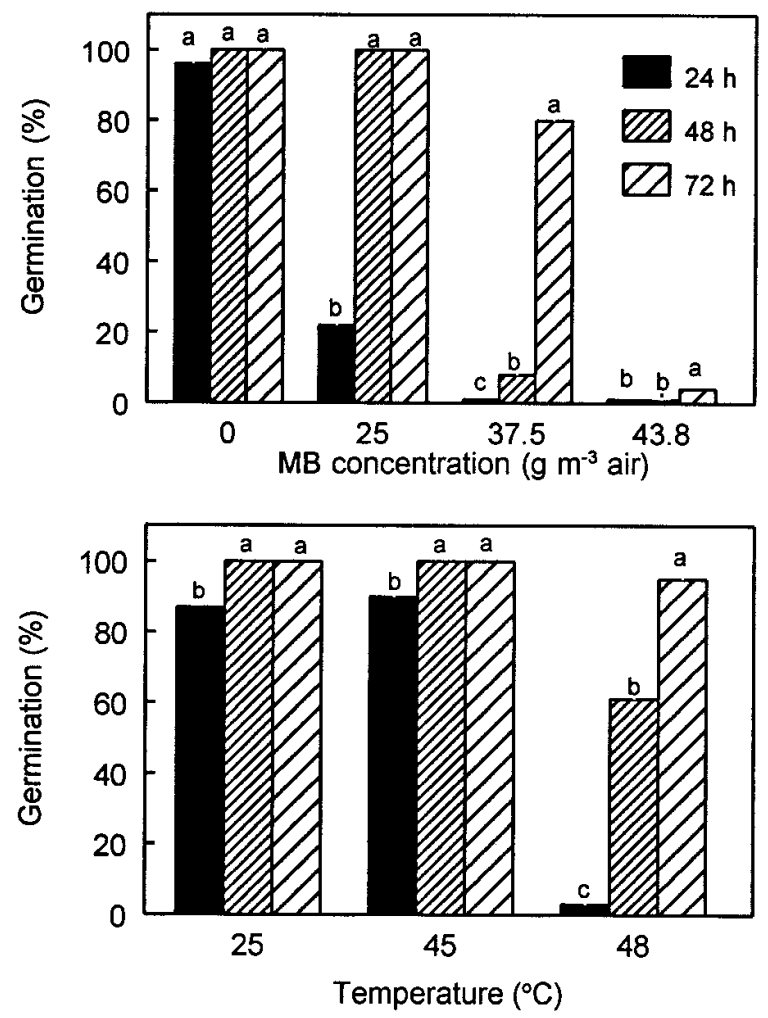

Fig. 2. The effects of methyl bromide (MB, $24 \mathrm{~h}$ of exposure) or heating ( $1 \mathrm{~h}$ of exposure) treatments under a controlled-environment system on germination of Sclerotium rolfsii sclerotia at three periods of incubation after treatment. For each MB concentration or heating treatment, columns topped with different letters are significantly different $(P \leq 0.05)$. the experimental error between the repeats. Analysis of the data showed no significant interaction between the treatments and the replicate experiments; thus, only the effect of the treatments (e.g., gas concentration, mortality of fungal propagules) is shown for the analyses. The percentage of killing was arcsine-transformed before analysis. The effect of heat and MB were tested by twoway analysis of variance. The combinations of heating or solarization and MB or metham sodium were compared by oneway analysis of variance and interaction effects were tested by contrast $t$ tests. Analysis for synergism was performed to evaluate fungal control by combined treatments, which was higher than the cumulative mortality level accomplished by each treatment alone. Synergism was expressed as the difference between mortality level accomplished by heating, solarization, or fumigant and the cumulative mortality value obtained by heating or solarization combined with fumigant. Inverse synergism indicated that the addition resulting from combination was less than additive. Significant difference from 0 was assessed using a $t$ test. All treatment means were compared simultaneously by the Tukey test. All analyses were performed with the SAS program (release 6.04 for PC, SAS Software, Cary, NC) at $P \leq 0.05$.

\section{RESULTS}

Effect of MB and heating at sublethal doses, alone or in combination, on pathogen viability. Exposure of $S$. rolfsii sclerotia to $\mathrm{MB}$ or heating affected rate and final percentage of germination (Fig. 2). Exposure of sclerotia to $\mathrm{MB}$ at 25 and $37.5 \mathrm{~g}$ $\mathrm{m}^{-3}$ or to heating at $48^{\circ} \mathrm{C}$ for $1 \mathrm{~h}$ resulted in a pronounced delay in germination, but the final percentage of germination was affected only at $37.5 \mathrm{~g} \mathrm{~m}^{-3}$. A similar trend of delayed germination by sublethal doses of $\mathrm{MB}$ and heating was obtained with macroconidia of $F$. oxysporum f. sp. basilici (results not shown). Based on these results and additional experiments, $\mathrm{MB}$ at $37.5 \mathrm{~g}$ $\mathrm{m}^{-3}$ and heating at $45^{\circ} \mathrm{C}$ for $2 \mathrm{~h}$ were used in the subsequent experiments as sublethal doses for treating $S$. rolfsii sclerotia. Exposure to heating or MB delayed germination, but after $48 \mathrm{~h}$, germination percentages were similar to the untreated control (Fig. 3). However, combining heating and fumigation (in both application sequences) delayed germination and significantly reduced, by synergistic effect, the final percentage of germination. The sequence involving heating first followed by fumigation with MB was significantly more effective than the opposite sequence in delaying and reducing germination of $S$. rolfsii sclerotia. A similar

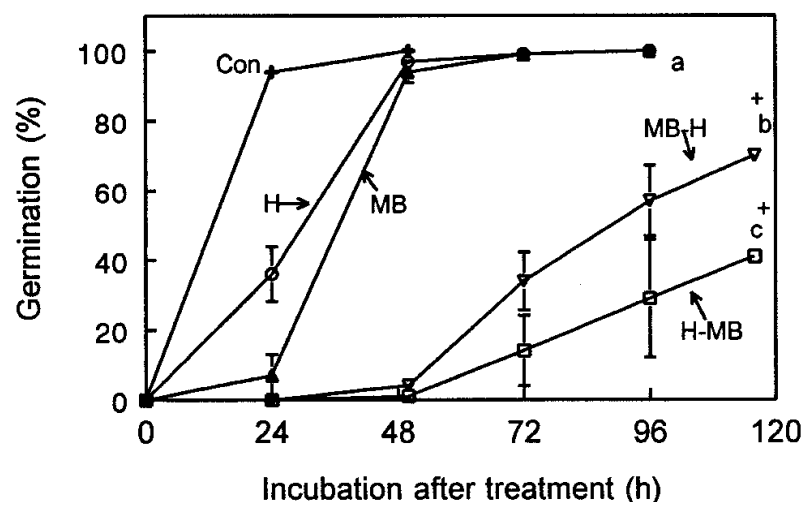

Fig. 3. The effects of methyl bromide (MB), heating $(\mathrm{H})$, and combinations of both in a controlled-environment system on germination of Sclerotium rolfsii sclerotia. Con $=$ nontreated sclerotia incubated at $25^{\circ} \mathrm{C} ; \mathrm{H}=$ heating at $45^{\circ} \mathrm{C}$ for $2 \mathrm{~h} ; \mathrm{MB}=$ exposure to $\mathrm{MB}$ at a concentration of $37.5 \mathrm{~g} \mathrm{~m}^{-3}$ of air for $24 \mathrm{~h}$ (concentration $\times$ time $=900 \mathrm{~g} \mathrm{~h} \mathrm{~m}^{-3}$ ); MB-H = application of $\mathrm{MB}$ followed by heating; H-MB = application of heating followed by MB. Values followed by different letters are significantly different $(P \leq 0.05)$. Bars indicate standard errors; + indicates significant synergistic effect in the related treatment $(P \leq 0.05)$. 
trend was obtained with killing $F$. oxysporum f. sp. basilici macroconidia (Fig. 4). Thus, a synergistic mortality effect was obtained by combining heating and MB treatments with the appropriate sequence of application.

Weakening of sclerotia and exposure to soil microbial activity. The delayed germination of $S$. rolfsii sclerotia resulting from sublethal heating or fumigation and the increased mortality of propagules of the two tested pathogens by combined treatments suggested a weakening effect $(11,18,20)$. Therefore, the effect of a further stress imposed on propagules that were previously treated with sublethal heating by exposure to soil microbial activity was examined.

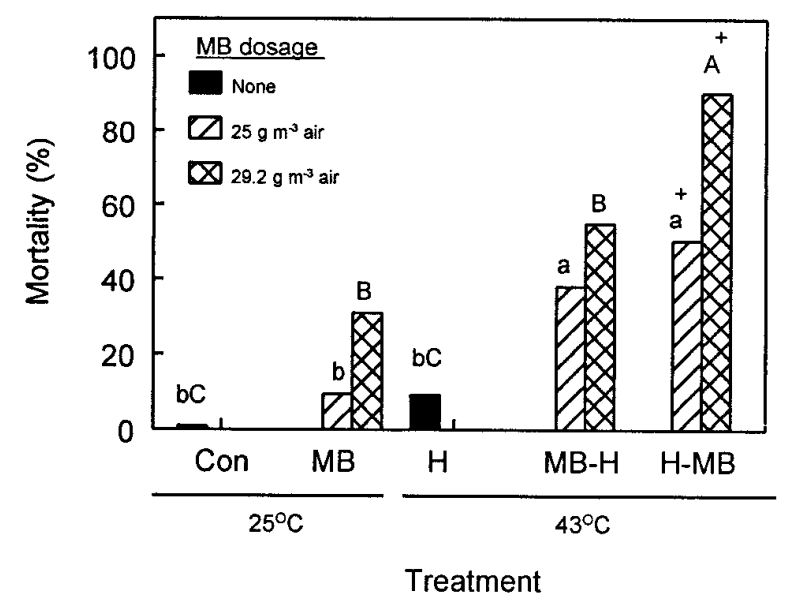

Fig. 4. The effects of methyl bromide (MB), heating $(\mathrm{H})$, and combinations of both in a controlled-environment system on survival of Fusarium oxysporum f. sp. basilici macroconidia. Con $=$ incubation at $25^{\circ} \mathrm{C}$; $\mathrm{MB}=$ exposure to $\mathrm{MB}$ at concentrations of 25 or $29.2 \mathrm{~g} \mathrm{~m}^{-3}$ of air for $24 \mathrm{~h}$ (concentration $\times$ time $=600$ and $700.8 \mathrm{~g} \mathrm{~h} \mathrm{~m}^{-3}$, respectively); $\mathrm{H}=$ heating at $43^{\circ} \mathrm{C}$ for $1 \mathrm{~h}$; $\mathrm{MB}-\mathrm{H}=$ application of $\mathrm{MB}$ followed by heating; $\mathrm{H}-\mathrm{MB}=$ application of heating followed by MB. For each MB concentration, columns topped with different uppercase or lowercase letters are significantly different $(P \leq 0.05)$. + indicates significant synergistic effect in the related treatment $(P \leq 0.05)$.

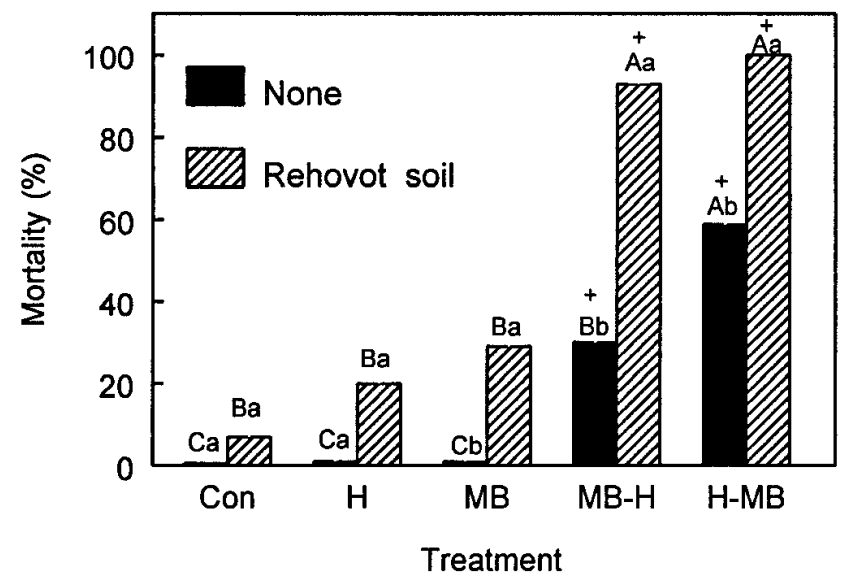

Fig. 5. Percent mortality of Sclerotium rolfsii sclerotia in a controlled environment after exposure to methyl bromide (MB), heating $(\mathrm{H})$, and combined treatments, either without (none) or with subsequent incorporation for 8 days in Rehovot soil. Con $=$ incubation at $25^{\circ} \mathrm{C} ; \mathrm{H}=$ heating at $45^{\circ} \mathrm{C}$ for $2 \mathrm{~h} ; \mathrm{MB}=$ exposure to $\mathrm{MB}$ at a concentration of $37.5 \mathrm{~g} \mathrm{~m}^{-3}$ air for $24 \mathrm{~h}$ (concentration $\times$ time $=900 \mathrm{~g} \mathrm{~h} \mathrm{~m}^{-3}$ ); MB-H = application of MB followed by heating; $\mathrm{H}-\mathrm{MB}=$ application of heating followed by MB. Within each set of propagule incorporation, columns topped with different uppercase letters are significantly different from each other $(P \leq 0.05)$. Within each pair of columns, different lowercase letters are significantly different from each other $(\mathrm{P} \leq 0.05) .+$ indicates significant synergistic effect in the related treatment $(\mathrm{P} \leq 0.05)$.
Previously MB- or heat-treated and untreated S. rolfsii sclerotia were incorporated into moistened Rehovot soil and incubated for 8 days. Sclerotial mortality was compared with that of similarly treated sclerotia that were kept in dry sterile sand for the same period. Results (Fig. 5) show that both heating and MB fumigation used alone, at the doses tested, were sublethal since they did not affect sclerotial viability ( 0 to $1 \%$ reduction in viability) when tested without exposure to soil microbial activity. However, soil incubation of heat or MB-treated sclerotia increased their mortality (up to $29 \%$ ). As previously shown, the combined heating-MB treatment increased mortality of the propagules and was synergistic. Their incubation in the soil and exposure to soil microbial activity further increased their mortality to 93 to $100 \%$. Again, the sequence of heating followed by MB treatment increased propagule sensitivity to the combined treatment. A similar trend was obtained at $\mathrm{MB}$ doses of $50 \mathrm{~g} \mathrm{~m}^{-3}$ (results not shown).

The effect of incorporating soil propagules that had been previously treated with low doses of $\mathrm{MB}$ was studied further in the field. Chlamydospores of $F$. oxysporum f. sp. melonis and $F$. oxysporum f. sp. radicis-lycopersici were incorporated into moistened agricultural soil in the field at four depths and fumigated with MB. The mortality of half of the samples was assessed immediately after termination of fumigation (2 days after application); the mortality of the other half was assessed after an additional 8 days of incubation in the soil. MB treatment resulted in various levels of mortality, depending on soil depth and the pathogen (Fig. 6). However, extended incubation of propagules in the fumigated field soil further decreased the survival of the two pathogens in most tested depths, confirming the laboratory results (Fig. 5).

Combined effect of fumigants and short solarization in field tests. The higher effectiveness of combined treatments in the control of various pathogens was further examined under field applications. Combinations of short solarization and $\mathrm{MB}$ or

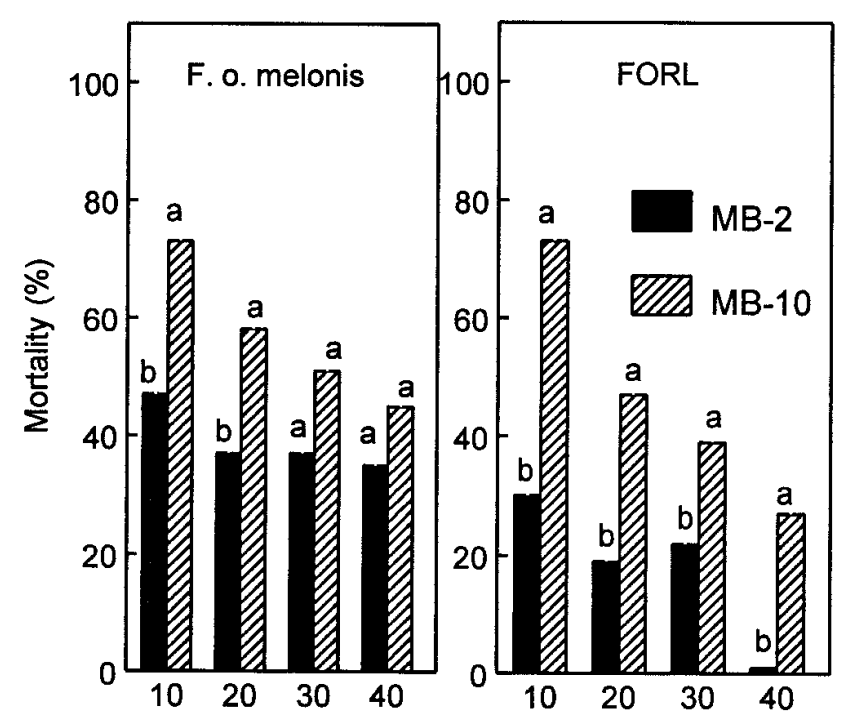

Soil depth $(\mathrm{cm})$

Fig. 6. Percent mortality of pathogen propagules in the field after low-dose $\left(10 \mathrm{~g} \mathrm{~m}^{-2}\right)$ fumigation with methyl bromide $(\mathrm{MB})$ (concentration $\times$ time values for $10,20,30$, and $40 \mathrm{~cm}$ depths were $245,221,181$, and 153, respectively). MB-2 $=$ Sample assessed immediately after termination of fumigation ( 2 days after application); MB-10 $=$ assessment was done 10 days after application; F. o. melonis = chlamydospores of Fusarium oxysporum $\mathrm{f}$. sp. melonis produced in soil; FORL $=$ soil naturally infested with $F$. oxysporum f. sp. radicis-lycopersici. For each pathogen, at every depth, columns topped with different letters are significantly different $(P \leq 0.05)$. Mortality was calculated by comparing with nontreated propagules. 
metham sodium, another common soil fumigant, both at low doses, were examined. $\mathrm{MB}$ at $10 \mathrm{~g} \mathrm{~m}^{-2}$ or metham sodium at 10 $\mathrm{ml} \mathrm{m}^{-2}$ are considered sublethal doses, since they are equivalent to $\approx 20 \%$ of the recommended dose for field application. Indeed, monitored $C \times T$ values were sublethal, as also shown previously (8). In most cases, the combined treatments were more effective than each treatment alone in controlling the four tested pathogens (Fig. 7). In certain cases, the combined treatment was synergistic, but there were also some instances of inverse synergism, namely, the effect was less than additive. With certain combinations, the sequence of solarization first followed by $\mathrm{MB}$ treatment was significantly more effective than the opposite treatment sequence. These findings again confirmed the results obtained under controlled conditions (Figs. 3 through 5). A similar trend with respect to the effect of application sequence was obtained with metham sodium (Fig. 8). At a depth of $10 \mathrm{~cm}$, both fumigants were highly effective even when each was applied alone, appar- ently due to the higher effectiveness of the treatments at that depth.

\section{DISCUSSION}

The optimal use of a combination of control agents is at the heart of a successful integrated pest management program, since it has the potential to improve pest control and broaden the spectrum of affected pests, reducing the dose of pesticide needed and extending the effectiveness of the treatments. Indeed, in our experiments, effective control of soilborne fungi was obtained using low doses of the control agents, with short exposure to heating or solarization, which were sublethal when used alone. The combination of solarization with other methods of control should be considered from two points of view: as a way of improving solarization, e.g., by shortening the length of the application from the standard 30 to 40 days to 8 days, and, as a
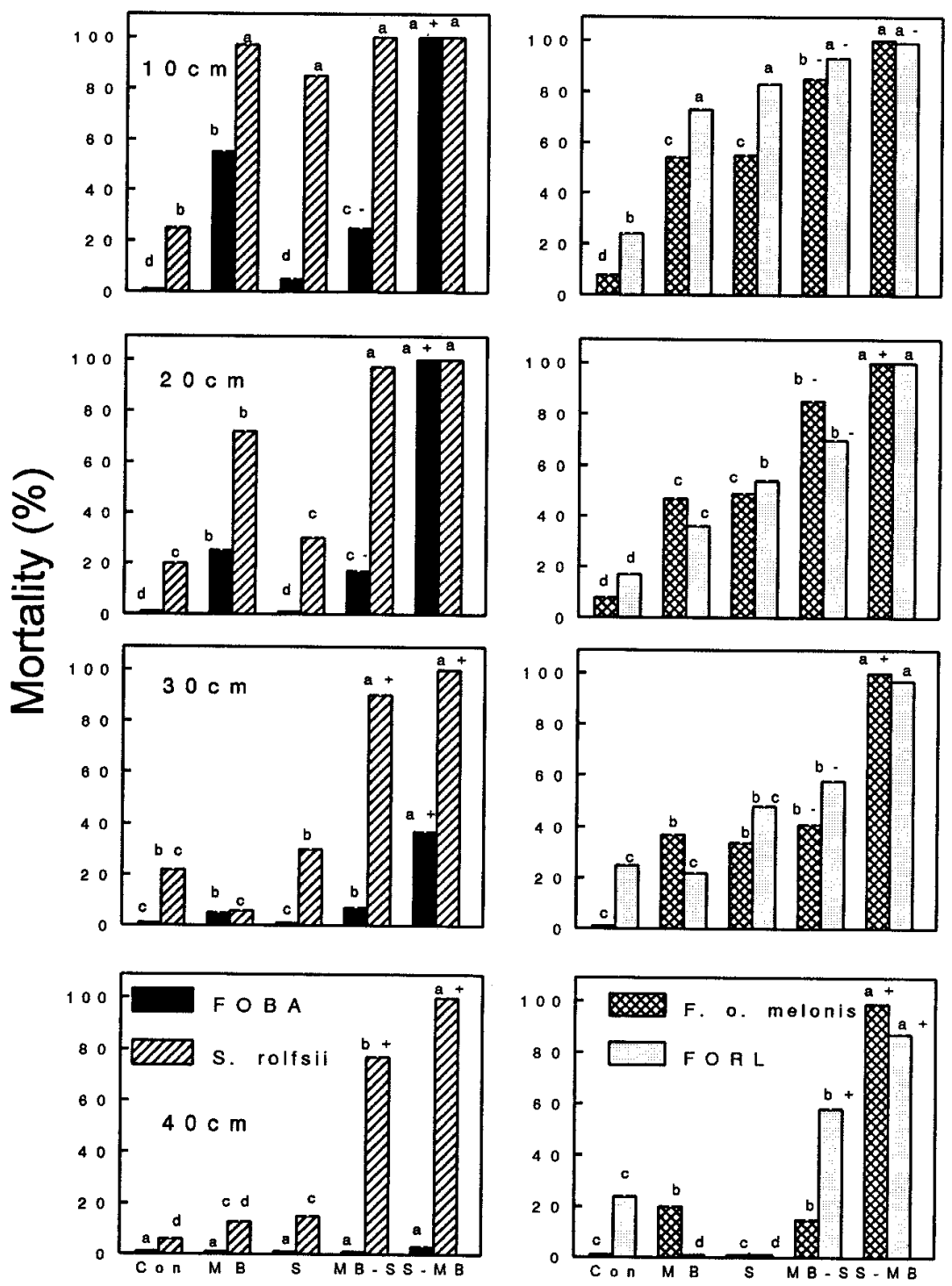

\section{Treatment}

Fig. 7. The effect of combined exposure to methyl bromide(MB) at a low dose $\left(10 \mathrm{~g} \mathrm{~m}^{-2}\right)$ and short solarization (S, 8 days) on percentage of propagule mortality at four depths in the field. Concentration $\times$ time values for 10,20,30, and $40 \mathrm{~cm}$ depths were 261, 237, 208, and 167, respectively. Con $=$ untreated control; MB-S = fumigation followed by solarization; S-MB = solarization followed by fumigation; FOBA = macroconidia from stems of diseased sweet basil naturally infected with Fusarium oxysporum f. sp. basilici; S. rolfsii = sclerotia of Sclerotium rolfsii; F. o. melonis $=$ chlamydospores of $F$. oxysporum f. sp. melonis produced in soil; FORL $=$ soil naturally infested with $F$. oxysporum f. sp. radicis-lycopersici. For each pathogen, columns topped with different letters are significantly different $(\mathrm{P} \leq 0.05)$; + indicates significant synergistic effect in the related treatment; - indicates significant inverse synergism $(P \leq 0.05)$. 
way of improving the other methods with which solarization is combined (17). From the latter point of view, a suitable combination of solarization with a reduced dose of a chemical pesticide should reduce the pesticide's harmful effects (and, thus, make it more acceptable) without reducing control effectiveness, but rather increasing it.

The present study shows that combining heating or short solarization with a reduced dose of either MB or metham sodium is more effective than each treatment alone in controlling a variety of fungal pathogens. A synergistic effect was frequently observed (Figs. 3 through 5, 7, 8). This was verified both under controlled conditions and in the field. For example, application of heating or MB under controlled conditions at doses that reduced the fungal pathogen by only 0 to $10 \%$ resulted in up to $90 \%$ pathogen control when appropriately combined (Figs. 3 through 5). Similarly, neither $\mathrm{MB}$ at $20 \%$ of the recommended dose nor a short solarization of 8 days could control the populations of $F$. oxysporum f. sp. basilici at a depth $20 \mathrm{~cm}$ or $S$. rolfsii at a depth of $40 \mathrm{~cm}$ under field conditions, while combining them in the appropriate sequence resulted in $100 \%$ reduction (Fig. 7). A
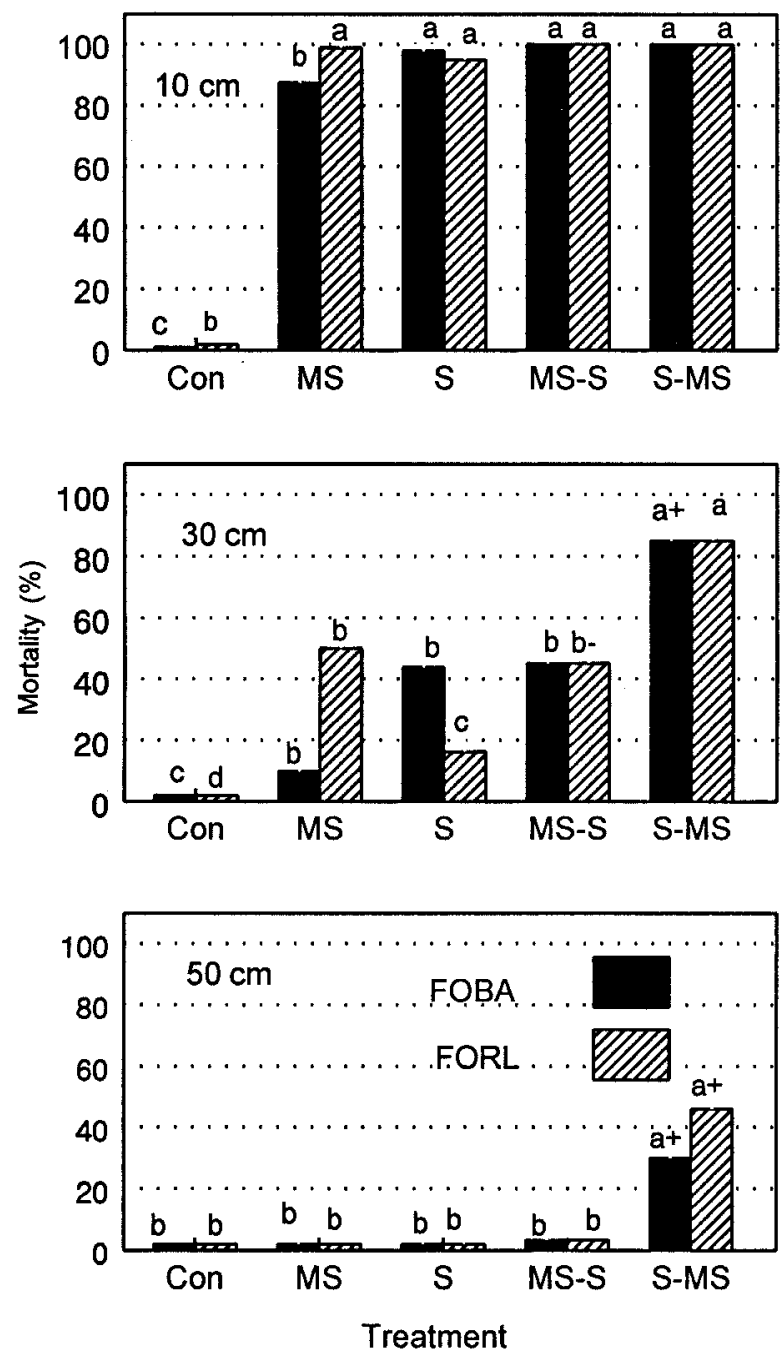

Fig. 8. The effect of combined exposure to metham sodium (MS) at low-dose $\left(10 \mathrm{ml} \mathrm{m}^{-2}\right)$ fumigation and short solarization $(\mathrm{S}, 8$ days $)$ on percentage of propagule mortality at three depths in the field. Con $=$ untreated control; MS$\mathrm{S}=$ fumigation followed by solarization; S-MS = solarization followed by fumigation; FOBA = stems of diseased sweet basil naturally infected by Fusarium oxysporum f. sp. basilici; FORL $=$ soil naturally infested with $F$. oxysporum f. sp. radicis-lycopersici. For each pathogen, columns topped with different letters are significantly different $(P \leq 0.05) .+$ indicates significant synergistic effect in the related treatment; - indicates significant inverse synergism $(P \leq 0.05)$. similar trend was obtained with metham sodium at $20 \%$ of the recommended dose (Fig. 8). Incubation of the propagules in soil (i.e., exposure to the activity of resident soil microorganisms) further improved pathogen control (Fig. 5)-a principle that was also verified under field conditions (Fig. 6). These findings also have practical applications: a period of time should be allowed between the termination of fumigation and planting to enable a further reduction in pathogen population. Thus, an assessment of pathogen populations immediately after treatment may not reflect the full potential of the treatment in terms of pathogen control. The lower effectiveness of fumigation, which has been encountered in certain cases, may be due to the fact that planting was carried out shortly after fumigation.

When pathogen populations are exposed to sublethal doses of a control agent, the surviving propagules are stressed and weakened and may become more vulnerable to other biotic or abiotic agents. This weakening effect is the basis of the synergistic action of combined treatments (18). We showed that sublethal doses of MB or heating, applied in a controlled environment system, delayed germination of $S$. rolfsii sclerotia (Fig. 2), which is a typical sign of weakening (20). The same trend has been obtained with $F$. oxysporum f. sp. niveum conidia, whose germ-tube elongation was reduced as a result of weakening by heat (11). Slower germination in the soil would extend the time during which the vulnerable germ tubes are exposed to hostile microbial activity. This diminishes the chance of the propagules successfully penetrating the plant tissues. Lifshitz et al. (20) found that sublethal heating increases the leakage of organic substances from sclerotia and subsequently stimulates invasion of the sclerotia by soil microorganisms, eventually leading to their decay. Similarly, heated chlamydospores of $F$. oxysporum f. sp. ciceri lost organic compounds, were more readily colonized by soil microorganisms, and sustained a further loss of viability and pathogenic aggressiveness (2). Germination and melanization of sublethally heated microsclerotia of Verticillium dahliae were slowed (23). The increased mortality rate of pathogen propagules treated with sublethal doses of fumigants or heating and subsequently incubated in soil (Figs. 5,6) may be attributed to similar mechanisms. Pretreatment of pathogen propagules by a sublethal dose of MB increased pathogen mortality, caused by soil microorganisms (Fig. 5). Thus, weakening of the propagules by sublethal treatment appears to trigger enhanced biological control by soil organisms by increasing their vulnerability. Enhanced colonization of weakened propagules by a Trichoderma was demon-strated long ago with $S$. rolfsii treated with formalin (6) and with an Armillaria treated with $\mathrm{CS}_{2}$, another mild fumigant (4). Garrett (15) thoroughly discussed this phenomenon, but unfortunately, the potential of this approach was not exploited, apparently due to the availability of powerful fumigants.

The sequence of application had a significant effect on the improved control of pathogens, as demonstrated in all tested systems (Figs. 3 through 5, 7, 8). Sublethal heating of sclerotia of $S$. rolfsii caused cracks in the sclerotia (20), which may facilitate the penetration of $\mathrm{MB}$ to the sclerotia and may explain why a sequence of first heating and then fumigating is more effective than the opposite sequence. The sequence of application should be thoroughly considered when planning treatment combinations. One practical recommendation based on our findings is to solarize the soil for a short period and later, to introduce the desired fumigant or biocontrol agent via a drip-irrigation system or other means.

Combining solarization with other control agents may enable a shortening of the solarization period. Thus, the solarizationmetham sodium combination killed more propagules of $F$. oxysporum f. sp. vasinfectum faster than solarization alone (3). Additional benefits of combining solarization with pesticides might include extending the retention of volatile pesticide trapped under the plastic mulch (14) and, possibly, activation of the 
pesticide when heated (1). The beneficial effect of combining solarization, heating, or fumigants with other control agents under field conditions has been demonstrated with a variety of crops and pathogens $(3,5,9,13,14,21-23)$. For example, combining metham sodium at a sublethal dose with a biocontrol agent reduced infection of eggplant by $V$. dahliae (10).

The present study shows that MB and metham sodium doses can be reduced, solarization can be shortened, and the effectiveness of pathogen control increased by properly combining the control agents. This approach should also be adopted with other pesticides and control agents and can be followed to develop technologies that are environmentally acceptable and more effective for pest management. This is especially necessary at present, when attempts are being made to replace MB with nonchemical methods rather than other fumigants, and consumption of this fumigant has to be immediately reduced.

\section{ACKNOWLEDGMENTS}

This research was supported by grants from Dead Sea Bromine Group Ltd., the MB Global Coalition (MBGC), and the Chief Scientist of the Israeli Ministry of Environmental Quality. Series cont. no. 742/99 from the Agricultural Research Organization, The Volcani Center, Bet Dagan, Israel. We thank Y. Gotlieb and the staff of the Hebrew University Experimental Farm for their cooperation; S. Erez, S. Lourie, B. Steiner, J. Rivan, and M. Bniches for their technical assistance, Plastopil Hazorea (Israel) for providing the plastic films; and Dead Sea Bromine Group (Israel) for providing the MB.

\section{LITERATURE CITED}

1. Aharonson, N., and Katan, J. 1991. Pesticide behavior in solarized and disinfected soils. Pages 131-138 in: Soil Solarization. J. Katan and J. E. DeVay, eds. CRC Press, Boca Raton, FL.

2. Arora, D. K., Pandey, A. K., and Srivastava, A. K. 1996. Effects of heat stress on loss of $\mathrm{C}$, germination and pathogenicity for chlamydospores of Fusarium oxysporum f. sp. ciceri. Soil Biol. Biochem. 28:399-407.

3. Ben-Yephet, Y., Melero, J. M., and DeVay, D. E. 1988. Interaction of soil solarization and metham-sodium in the destruction of Verticilium dahliae and Fusarium oxysporum f. sp. vasinfectum. Crop Prot. 7:327331.

4. Bliss, D. E. 1951. The destruction of Armillaria mellea in citrus soils. Phytopathology 41:665-683.

5. Chellemi, D. O., Olson, S. M., and Mitchell, D. J. 1994. Effects of soil solarization and fumigation on survival of soilborne pathogens of tomato in northern Florida. Plant Dis. 78:1167-1172.

6. Davey, A. E., and Leach, L. D. 1941. Experiments with fungicides for use against Sclerotium rolfsii in soils. Hilgardia 10:523-547.
7. Dhingra, O. D., and Sinclair, J. B. 1986. Basic Plant Pathology Methods. CRC Press, Boca Raton, FL.

8. Eshel, D., Gamliel, A., Katan, J., and Grinstein A. 1999. Evaluation of soil fumigants on soilborne fungal pathogens in a controlledenvironment system and in soil. Crop Prot. 18:437-443.

9. Frank, Z. R., Ben-Yephet, Y., and Katan, J. 1986. Synergistic effect of metham and solarization in controlling delimited shell spots of peanut pods. Crop Prot. 5:199-202.

10. Fravel, D. R. 1996. Interaction of biocontrol fungi with sublethal rates of metham sodium for control of Verticillium dahliae. Crop Prot. 15:115119.

11. Freeman, S., and Katan, J. 1988. Weakening effect on propagules of Fusarium by sublethal heating. Phytopathology 78:1656-1661.

12. Gamliel, A., Grinstein, A., Klein, L., Cohen, Y., and Katan, J. 1998. Permeability of plastic to methyl bromide: Field study. Crop Prot. 17:241-248.

13. Gamliel, A., Hadar, E., and Katan, J. 1993. Improvement of growth and yield of Gypsophila paniculata by solarization or fumigation of soil or container medium in continuous cropping systems. Plant Dis. 77:933938.

14. Gamliel, A., and Stapleton, J. J. 1993. Effect of chicken compost or ammonium phosphate and solarization on pathogen control, rhizosphere microorganisms, and lettuce growth. Plant Dis. 77:886-891.

15. Garrett, S. D. 1956. Biology of Root-Infecting Fungi. Cambridge University Press, Cambridge.

16. Grinstein, A., Kritzman, G., Hetzroni, A., Gamliel, A., Mor, M., and Katan, J. 1995. The border effect of soil solarization. Crop Prot. 14:315320 .

17. Katan, J. 1996. Soil solarization: Integrated control aspects. Pages 250278 in: Principles and Practice of Managing Soilborne Plant Pathogens. R. Hall, ed. American Phytopathological Society Press, St. Paul, MN.

18. Katan, J., Ginzburg, C., and Freeman, S. 1992. The weakening effect as a trigger for biological control and criteria for its evaluation. Pages 5561 in: Biological Control of Plant Diseases. E. C. Tjamos, G. Papavizas, and R. Cook, eds. Plenum Press, New York.

19. Klein, L. 1996. Methyl bromide as a soil fumigant. Pages 191-235 in: The Methyl Bromide Issue. C. H. Bell, N. Price, and B. Chakrabarti, eds. Wiley and Sons, New York.

20. Lifshitz, R., Tabachnik, M., Katan, J., and Chet, I. 1983. The effect of sublethal heating on sclerotia of Sclerotium rolfsii. Can. J. Microbiol. 29:1607-1610.

21. Ristaino, J. B., Perry, K. B., and Lumsden, R. D. 1991. Effect of solarization and Gliocladium virens on sclerotia of Sclerotium rolfsii, soil microbiota, and the incidence of southern blight of tomato. Phytopathology 81:1117-1124.

22. Sivan, A., and Chet, I. 1993. Integrated control of Fusarium crown and root rot of tomato with Trichoderma harzianum in combination with methyl bromide or soil solarization. Crop Prot. 12:380-386.

23. Tjamos, E. C., and Fravel, D. R. 1995. Detrimental effects of sublethal heating and Talaromyces flavus on microsclerotia of Verticillium dahliae. Phytopathology 85:388-392. 